ZOOLOGIA 27 (2): 201-208, April, 2010

doi: $10.1590 /$ S1984-46702010000200007

\title{
Ecology of Ischnocnema parva (Anura: Brachycephalidae) at the Atlantic Rainforest of Serra da Concórdia, state of Rio de Janeiro, Brazil
}

\author{
Ana Cristina J. S. Martins'; Mara C. Kiefer²; Carla C. Siqueira ${ }^{1}$; Monique Van Sluys ${ }^{1}$; \\ Vanderlaine A. Menezes ${ }^{1} \&$ Carlos Frederico D. Rocha ${ }^{1}$
}

\author{
${ }^{1}$ Departamento de Ecologia, Universidade do Estado do Rio de Janeiro. Rua São Francisco Xavier 524, 20550-019 Rio de \\ Janeiro, Rio de Janeiro, Brazil. E-mail: cfdrocha@uerj.br \\ ${ }^{2}$ Departamento de Biologia Geral, Instituto de Biologia, Universidade Federal Fluminense. Caixa Postal 100436, Centro, \\ 24020-971 Niterói, Rio de Janeiro, Brazil.
}

\begin{abstract}
Ischnocnema (Brachycephalidae) includes many species that are important members of the leaf litter frog communities in the Atlantic Rainforest of Brazil. Ischnocnema parva (Girard, 1853) is endemic to the Atlantic Rainforest biome and is restricted to the forests of southeastern Brazil. Currently, the available information about the ecology of $I$. parva is scarce. We studied the diet, the habitat use, reproduction and density of $I$. parva in an area of Atlantic Rainforest at the Concórdia mountain range, Rio de Janeiro. Individuals of $I$. parva were captured in April 2005 using different sampling methods: time constrained search (transects), plots of $5 \times 5 \mathrm{~m}\left(25 \mathrm{~m}^{2}\right)$ on the litter, and pitfall traps with drift fences. We found 240 frogs; 35 females and 205 males. Females (mean SVL $=19.1 \mathrm{~mm}$ ) were significantly larger $\left(F_{1,238}\right.$ $\left.=143.016, \mathrm{R}^{2}=0.375, \mathrm{p}<0.001\right)$ than males $(13.2 \mathrm{~mm})$. The species preyed mainly on arthropods, with ants and isopods being the most important items, both showing high values of importance index (Ix $=50.0$ and 26.7, respectively). Ischnocnema parva is a terrestrial species whose preferential microhabitat at the Serra da Concórdia was the litter of the forest floor (78.7\%). The activity was predominantly crepuscular-nocturnal and the estimated density of $I$. parva was $24.9 \mathrm{ind} / 100 \mathrm{~m}^{2}$. For the eight ovigerous females captured, the mean number of mature oocytes per female was 25 (range: 22-30) and the oocyte mean diameter was $1.11 \mathrm{~mm}(\mathrm{~N}=40$ oocytes). Oocyte number increased with female body size $\left(\mathrm{R}^{2}=0.504, \mathrm{~F}_{1,6}=6.107, \mathrm{p}<0.05, \mathrm{~N}=8\right)$, indicating that as females increase in size they produce larger clutches. Some ecological aspects such as diet and microhabitat use were similar to that observed for an insular population of I. parva, whereas reproductive traits differed. Thus, long term studies are necessary to understand the extent to which these differences are explained by environmental factors.
\end{abstract}

KEY WORDS. Activity; density; diet; habitat use; reproduction.

Ischnocnema Reinhardt \& Lütken, 1862 includes several species that are important members of the leaf litter frog communities in the floor of the Atlantic Rainforest biome. Its current distribution includes areas of Atlantic forest in southeastern Brazil and savannas in central-western Brazil and northern Argentina (Frost 2008). These species were previously included in Eleutherodactylus Duméril \& Bibron, 1841 and were relocated following molecular analyses (HeInICKE et al. 2007). Individuals of Ischnocnema are usually abundant where they occur (e.g. Rосна et al. 2000, 2001) and are relatively easy to locate in the field (LyNCh \& Duellman 1997) and therefore can be considered suitable for ecological studies (e.g., Rocha et al. 2000, 2001). These frogs are characterized by the direct development of their terrestrial eggs (Haddad \& Prado 2005, Pombal \& Haddad 2007).

Ischnocnema parva (Girard, 1853) (formerly Eleutherodactylus parvus) is a small anuran species (females up to $26.0 \mathrm{~mm}$; males up to $23.0 \mathrm{~mm}$ snout-vent length; MarRa et al. 2004), endemic to the Atlantic Rainforest in southeast Brazil. The species occurs in the southeast portion of the state of Minas Gerais and in the states of Espírito Santo, Rio de Janeiro and São Paulo (Frost 2008). Despite being distributed along a relatively large area, information on the ecology of I. parva is mostly restricted to five studies, two of which (Heyer et al. 1990, Bertoluci \& RODRIGUES 2002) provide information on calling activity of this frog in Boracéia (state of São Paulo), whereas all other three were conducted at the insular environment of Ilha Grande (municipality of Angra dos Reis, state of Rio de Janeiro), which provided information on density, activity and diet (Rосна et al. 2000, 2001, MARra et al. 2004).

In the Atlantic Rainforest of Serra da Concórdia, western state of Rio de Janeiro, I. parva was one of the most abundant species of the leaf litter frog community. Herein, we studied the ecology of I. parva at Serra da Concórdia, investigating its diet, activity, habitat use, density and reproduction. Based on the in- 
formation obtained, we compared the traits of this population from the Serra da Concórdia (mainland) with those available in the literature, and evaluated to what extent they are similar to the insular population of Ilha Grande. Specifically, we aimed to answer the following questions: I) what is the diet composition of I. parva and what are the types of prey preferably consumed? II) To what extent does mouth size affects the size of prey consumed? III) What are the daily activity patterns of I. parva? IV) What are the main microhabitats used by these frogs? V) What is the density of I. parva at Serra da Concórdia? VI) What are the clutch size and reproductive effort of gravid females?

\section{MATERIAL AND METHODS}

This study was conducted at the Santo Antônio da Aliança farm, an area partly included in the Santuário de Vida Silvestre da Serra da Concórdia $\left(22^{\circ} 22^{\prime} \mathrm{S}, 43^{\circ} 47^{\prime} \mathrm{W}\right)$, in the municipalities of Barra do Piraí and Valença, state of Rio de Janeiro. The farm has an area of $295 \mathrm{ha}$, with altitudes ranging from 600 to $925 \mathrm{~m}$ above sea level. The area is covered by Atlantic forest at different levels of regeneration, and the best preserved areas are located, in general, at the less accessible portions of the forest. The vegetation of the area consists predominantly of Semideciduous Seasonal Forest (AtтiAs et al. 2009). Mean annual temperature is $20.4^{\circ} \mathrm{C}$ and varies from $10.8^{\circ} \mathrm{C}$ (winter) to $28.7^{\circ} \mathrm{C}$ (summer), and mean annual rainfall in the region is about $1469 \mathrm{~mm}$ (AtтiAs et al. 2009).

Fieldwork was carried out along 20 days on April 2005, using three methods of capture: active search (CRUMP \& SCOTT 1994), $25 \mathrm{~m}^{2}$ plots (or quadrats; JAEGER \& INGER 1994) established on the forest floor, and pitfall traps with drift fences (CORN 1994). Active search was performed by time-constrained transects (30 minutes). During each transect, the observer walked slowly through the forest carefully looking for frogs on the floor, under and on logs, twigs, roots and stones, as well as on the vegetation. In addition, some water bodies such as shallow rivulets and streams were also surveyed. Transects were conducted during the day (09:00 to $16: 00 \mathrm{~h})$, dusk (17:30 to $18: 30 \mathrm{~h})$ and at night (19:00 to $22: 00 \mathrm{~h}$ ), for a total of 120 transects (= 60 hours of search), 40 per period ( $=20$ hours of search/period).

For the plot method we established 18 quadrats of $5 \times 5 \mathrm{~m}$ on the forest floor during the afternoon, for a total of $450 \mathrm{~m}^{2}$ of sampled forest floor. We marked the corners of each plot with wooden stakes and the area inside was enclosed with a $50 \mathrm{~cm}$ high soft plastic fence, whose base was buried or attached to the ground. At night, each plot was carefully searched (for about half an hour, on average) by a crew of five persons wearing head lamps, moving on hands and knees, side-by-side. Within each plot, leaves, branches and stones were overturned with the aid of hand rakes and rock crevices and spaces among tree roots were also checked. All individuals of $I$. parva found were captured. Based on the number of individuals of $I$. parva sampled in these plots we estimated the density in the leaf litter of Serra da Concórdia in terms of number of frogs per $100 \mathrm{~m}^{2}$.
Additional specimens of $I$. parva were captured using pitfall traps with drift fences. Three pitfall trap systems were used during the 20 days of fieldwork. Each system consisted of ten 30-liter buckets buried on the ground and set $c a .5 \mathrm{~m}$ apart, with soft plastic drift fences about $50 \mathrm{~cm}$ high extended between them. Six buckets were set in line and the remaining four were placed at opposite ends of the fence, perpendicularly to the main axis. Pitfalls were checked once per day (always in the morning).

After capture, the frogs were immediately identified, killed in a $10 \%$ alcohol solution, fixed in $10 \%$ formalin solution and then preserved in a $70 \%$ alcohol solution. In the laboratory, the SVL and jaw width (JW) of individuals were measured with a digital caliper (to the nearest $0.1 \mathrm{~mm}$ ). The mass (in grams) of individuals was recorded using an electronic balance (to the nearest $0.001 \mathrm{~g}$ ). The sex of frogs was identified and recorded after dissection. We tested for sexual differences in body size (SVL) using one-way analysis of variance (ANOVA) (ZAR 1999).

The items found in the stomachs were identified and characterized to the taxonomic level of order or family (in the case of Formicidae). In the case of Coleoptera and Lepidoptera, the items were classified according to the stage of development (larvae or adult). Prey remains that could not be identified were grouped into a category "unidentified arthropod remains" (UAR). For each stomach the items were counted and measured in their length (L) and width (W) with a digital caliper (precision of $0.1 \mathrm{~mm}$ ). Diet composition was analyzed in terms of number, volume and frequency of occurrence of each type of prey. The volume of each item (in $\mathrm{mm}^{3}$ ) was estimated by the formula of the spheroid: $\mathrm{V}=4 / 3 \pi(\mathrm{L} / 2)(\mathrm{W} / 2)^{2}$, using the values of length and width (Dunham 1983). The frequency of occurrence of each item in the diet was estimated based on the number of frogs containing a given item in its stomach in relation to the total number of individuals sampled. For each category of prey, we calculated an index of importance (Ix), which represents the sum of the percentages of the number, volume and frequency of each item divided by three $[\mathrm{Ix}=(\% \mathrm{~N}+\% \mathrm{~V}$ $+\%$ F)/3] (Powell et al. 1990). To assess whether the number and size of items consumed were related to body and mouth sizes, the number and mean volume (both log-transformed) of prey per stomach were related, respectively, with frog SVL and JW, using Simple Linear Regression Analysis (ZAR 1999).

To evaluate the patterns of microhabitat use, only those individuals sampled during active searches were considered. For each individual, the type of substrate on which the animal was found when first seen was recorded.

To assess at what time of day I. parva individuals were predominantly active, frog activity was estimated on the number of frogs found during the transects performed with active search. This method was used due to the same sampling effort in different periods of the day.

Additionally, we analyzed the reproductive parameters of mean size of eggs, the mean number of eggs in the ovaries and reproductive effort. For these analyses, only females with ma- 
ture oocytes were considered. For each reproductive female, the number of oocytes was counted, their total mass was recorded with an electronic balance (to the nearest $0.001 \mathrm{~g}$ ) and the diameter of five of them was measured using a digital caliper (to the nearest $0.1 \mathrm{~mm}$ ). To evaluate if the size of ovigerous females affected the number of eggs produced or the mass of the clutch, the SVL of females was related to the number and mass of eggs (both log-transformed) through Simple Linear Regression Analysis. Reproductive effort was estimated by dividing the total mass of eggs by the body mass of the female, including eggs.

The results for the descriptive statistics are presented throughout the text as mean \pm 1 standard deviation. All data were tested for homoscedasticity of variances and for the normality of distribution before performing statistical analyses.

\section{RESULTS}

We analyzed a total of 240 individuals, of which 20 (8.3\%) had empty stomachs. We identified 20 types of food items in a total of 659 items (Tab. I). In terms of number of items, the most common prey were Hymenoptera Formicidae (58.1\%) and Isopoda (12.4\%). Volumetrically, the highest proportion of total prey consumed was that of Isopoda (35.9\%) followed by Hymenoptera Formicidae (24.3\%). Hymenoptera Formicidae and Isopoda were also the most frequent items in the analyzed stomachs (present in 67.7 and $31.8 \%$ of stomachs respectively). Hymenoptera Formicidae (50\%) and Isopoda (26.7\%) had the highest values of relative importance index of prey in the diet. We found plant remains in the stomachs of 21 individuals (8.7\%),

Table I. Number $(\mathrm{N})$, volume $\left(\mathrm{V}, \mathrm{mm}^{3}\right)$, frequency of occurrence $(\mathrm{F})$ (percentage in parenthesis) and Importance Index (Ix) of each food item in the diet of I. parva $(\mathrm{N}=220)$ in Santuário Ecológico da Serra da Concórdia, Barra do Piraí/Valença. (UAR) Unidentified arthropod remains.

\begin{tabular}{|c|c|c|c|c|}
\hline Items & N (\%) & V (\%) & F (\%) & Ix \\
\hline Gastropoda & $3(0.5)$ & $1.1(0.06)$ & $3(1.4)$ & 0.7 \\
\hline \multicolumn{5}{|l|}{ Arachnida } \\
\hline Scorpiones & $7(1.1)$ & $4.3(0.2)$ & $7(3.2)$ & 1.5 \\
\hline Araneae & $27(4.1)$ & $51.1(2.8)$ & $23(10.5)$ & 5.8 \\
\hline Opiliones & $8(1.2)$ & $79.7(4.4)$ & $8(3.7)$ & 3.1 \\
\hline Acari & $30(4.6)$ & $10.1(0.6)$ & $24(10.9)$ & 5.4 \\
\hline Chilopoda & $12(1.8)$ & 64.9 (3.6) & $10(4.5)$ & 3.2 \\
\hline \multicolumn{5}{|l|}{ Malacostraca } \\
\hline Isopoda & $82(12.4)$ & 646.7 (35.9) & $70(31.8)$ & 26.7 \\
\hline Decapoda & $1(0.2)$ & $0.5(0.02)$ & $1(0.5)$ & 0.2 \\
\hline \multicolumn{5}{|l|}{ Hexapoda } \\
\hline Collembola & $20(3.0)$ & $3.9(0.2)$ & $17(7.7)$ & 3.6 \\
\hline Orthoptera & $16(2.4)$ & $107.7(6.0)$ & $16(7.3)$ & 5.2 \\
\hline Isoptera & $2(0.3)$ & $35.1(1.9)$ & $2(0.9)$ & 1.0 \\
\hline Blattodea & $8(1.2)$ & $41.7(2.3)$ & $8(3.6)$ & 2.4 \\
\hline Hemiptera & $3(0.5)$ & $2.9(0.2)$ & $3(1.4)$ & 0.7 \\
\hline Homoptera & $3(0.5)$ & $27.1(1.5)$ & $2(0.9)$ & 0.9 \\
\hline \multicolumn{5}{|l|}{ Coleoptera } \\
\hline Adults & $15(2.3)$ & $32.5(1.8)$ & $14(6.4)$ & 3.5 \\
\hline Larvae & $9(1.4)$ & $14.6(0.8)$ & $9(4.1)$ & 2.1 \\
\hline \multicolumn{5}{|l|}{ Hymenoptera } \\
\hline Formicidae & $383(58.1)$ & $438.2(24.3)$ & 149 (67.7) & 50.0 \\
\hline Others & $8(1.2)$ & $12.0(0.7)$ & $6(2.7)$ & 1.5 \\
\hline \multicolumn{5}{|l|}{ Lepidoptera } \\
\hline Larvae & $4(0.6)$ & 83.9 (4.7) & $4(1.8)$ & 2.4 \\
\hline Diptera & $18(2.7)$ & $14.2(0.8)$ & $17(7.7)$ & 3.7 \\
\hline UAR & - & $28.4(1.6)$ & - & - \\
\hline Plant Remains & - & $101.5(5.6)$ & $21(8.7)$ & - \\
\hline Total & 659 & 1802.1 & - & - \\
\hline
\end{tabular}


representing $5.6 \%$ of the total volume of the contents (Tab. I). In all cases plant remains corresponded to fragments of dead leaves. The number of items ingested per frog (mean $=3.2 \pm 2.5$, range: $1-24, \mathrm{~N}=215$ ) was not significantly related (Regression Analysis, $\mathrm{R}^{2}=0.009, \mathrm{~F}_{1,213}=1.998, \mathrm{p}=0.159$ ) to frog SVL (mean $14.1 \pm$ $3.4 \mathrm{~mm}$, range: $6.7-25.5, \mathrm{~N}=240$ ), whereas the mean volume of items ingested $\left(\right.$ mean $=3.4 \pm 6.8 \mathrm{~mm}^{3}$; range: $0.01-77.0, \mathrm{~N}=220$ ) was significantly $\left(\mathrm{R}^{2}=0.249, \mathrm{~F}_{1,218}=72.336, \mathrm{p}<0.001\right)$ related to jaw width (mean $5.1 \pm 1.1$, range: $2.5-7.9 \mathrm{~mm}, \mathrm{~N}=220$ ) (Fig. 1 ).

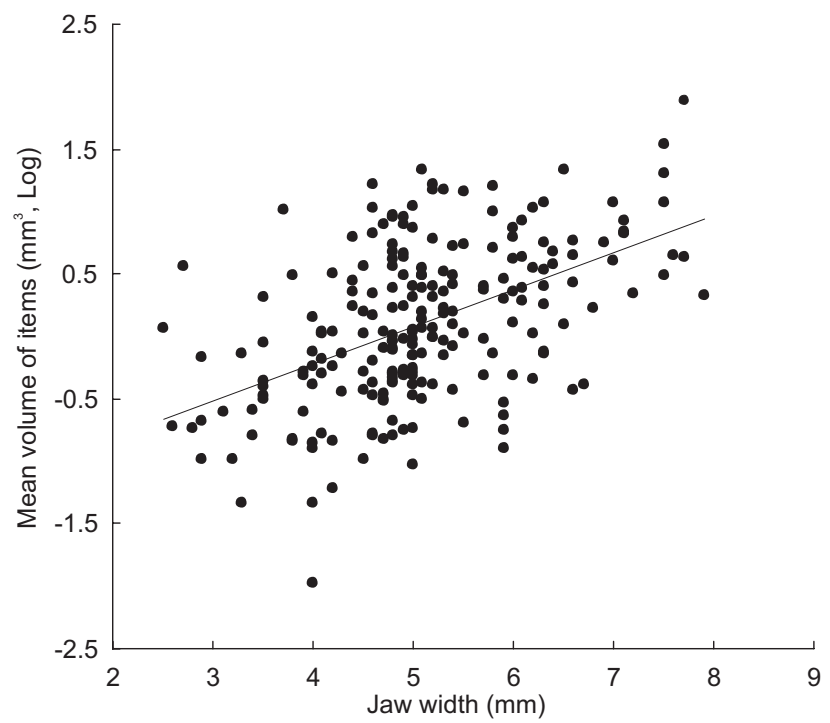

Figure 1. Relationship between jaw width $(\mathrm{mm})$ and mean volume $\left(\mathrm{mm}^{3}\right)$ of food items (in log) ingested by I. parva in Santuário Ecológico da Serra da Concórdia.

Active individuals of $I$. parva found during active search transects $(\mathrm{N}=47)$ used four categories of microhabitats, of which the leaf litter on the forest floor $(78.7 \%)$ was the most frequently used (Fig. 2). In terms of activity, 33 individuals (70.2\%) were active during the crepuscular period, 12 (25.5\%) during the night and two (4.2\%) during the day. The estimated density for I. parva on the leaf litter of Santuário Ecológico da Serra da Concórdia was $24.9 \mathrm{ind} / 100 \mathrm{~m}^{2}$.

The mean body size (SVL) of females $(19.1 \pm 3.1 \mathrm{~mm}$, range $=9.8-25.5 \mathrm{~mm}, \mathrm{~N}=35$ ) was significantly larger (ANOVA, $\left.\mathrm{F}_{1,238}=143.020, \mathrm{R}^{2}=0.370, \mathrm{p}<0.001\right)$ than that of males $(13.2$ $\pm 2.6 \mathrm{~mm}$, range $=6.7-21.6 \mathrm{~mm}, \mathrm{~N}=205$ ) (Fig. 3).

Eight females were ovigerous and had a mean SVL of 19.2 $\pm 0.8 \mathrm{~mm}$ (range: $17.8-20.0 \mathrm{~mm}$ ). The average number of eggs per female was $24.9 \pm 2.6$ (range: $22-30$ ), with $10.1 \pm 1.5$ (range: 8 -12) oocytes in the right ovary and $14.7 \pm 1.5$ (range: $13-18$ ) in the left ovary. The average diameter of oocytes was $1.11 \pm 0.38$ $\mathrm{mm}$ (range: $0.4-1.6 \mathrm{~mm}, \mathrm{~N}=40$ ) and the mean mass of eggs per female was $0.024 \pm 0.013 \mathrm{~g}$ (range: $0.010-0.053 \mathrm{~g}, \mathrm{~N}=8$ ). The

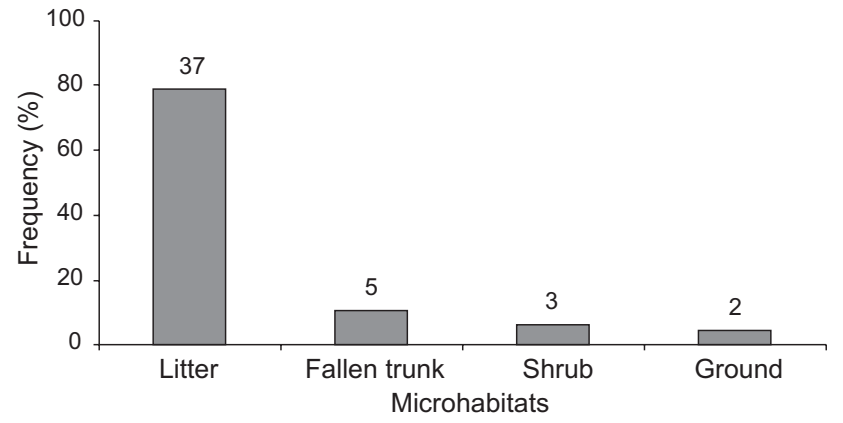

Figure 2. Frequency of use of different microhabitat categories by $I$. parva in Santuário Ecológico da Serra da Concórdia. Values above the bars indicate the number of individuals.

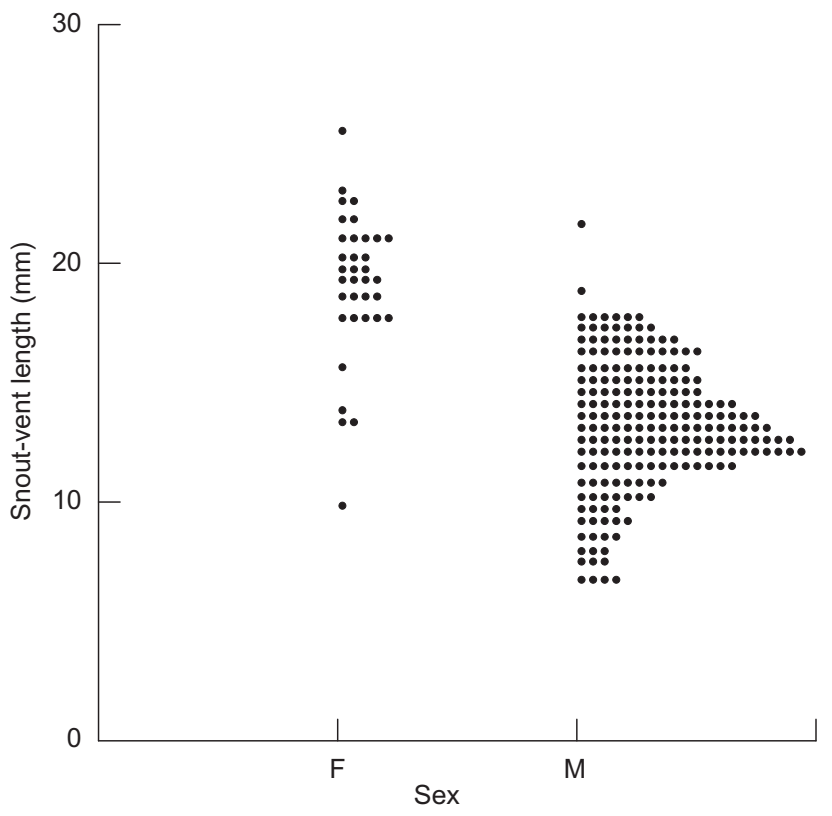

Figure 3. Body size distribution (snout-vent length, in $\mathrm{mm}$ ) of males (M) and females ( $F)$ of I. parva $(\mathrm{N}=220)$ in Santuário Ecológico da Serra da Concórdia.

number of oocytes in ovaries was positive and significantly related to females' SVL $\left(\mathrm{R}^{2}=0.504, \mathrm{~F}_{1,6}=6.107, \mathrm{p}<0.05, \mathrm{~N}=8\right)$ (Fig. 4), but there was a marginally significant relationship between the total mass of oocytes and female SVL $\left(\mathrm{R}^{2}=0.48, \mathrm{~F}_{1,6}=\right.$ $5.608, \mathrm{p}=0.056, \mathrm{~N}=8$ ) (Fig. 5). The reproductive effort of ovigerous females averaged $3.1 \pm 1.2 \%$ (range: $1.9-5.6 \%, \mathrm{~N}=8$ ).

\section{DISCUSSION}

Individuals of I. parva at the Serra da Concórdia feed predominantly on arthropods. Formicidae and Isopoda were the main prey types in the frog's diet. Formicidae and Isopoda were 


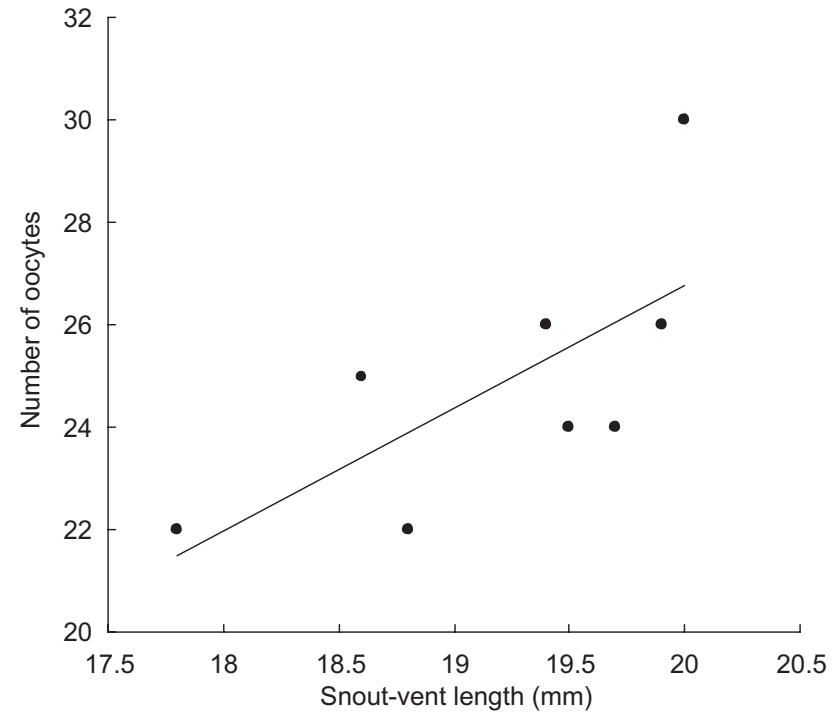

Figure 4. Relationship between snout-vent length ( $\mathrm{mm}$ ) and number of oocytes of ovigerous females (in log) of I. parva in Santuário Ecológico da Serra da Concórdia.

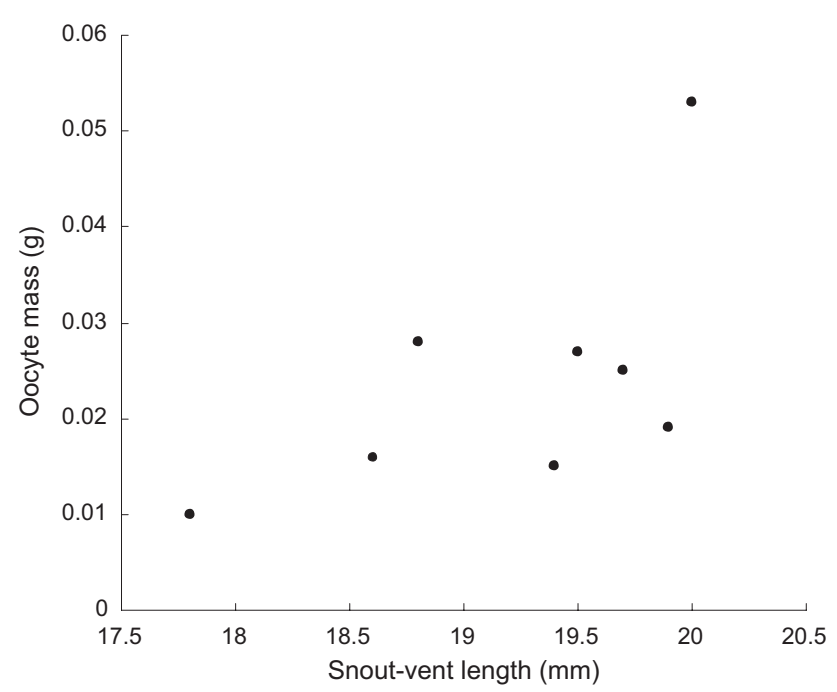

Figure 5. Relationship between snout-vent length $(\mathrm{mm})$ and oocyte mass (g) of ovigerous females (in log) of I. parva in Santuário Ecológico da Serra da Concórdia.

also important prey in the diet of the population studied in the forest of Ilha Grande, in the state of Rio de Janeiro (MARRA et al. 2004). These results suggest that $I$. parva tend to feed predominantly on these arthropods, even living in different areas (insular and mainland). Formicidae are usually dominant among the arthropods living in the Atlantic forest leaf litter, during both the dry and rainy seasons (LACERDA et al. 1998, SANTOS et al. 1998).
There was a higher proportion of Araneae in the diet of the population of I. parva at Ilha Grande (see MARRA et al. 2004) compared to that of Serra da Concórdia, but since we have no data on prey availability for both areas, we do not know to what extent the differential consumption between these two sites reflects differences in availability of this prey type.

In the Atlantic forest, other leaf litter frogs also consume mainly arthropods. At Ilha Grande, the diet of Leptodactylus marmoratus (Steindachner, 1867) (Leptodactylidae) consisted mainly of Isopoda, insect larvae and Formicidae (ALMEIDA-GomES et al. 2007). In the same area, Zachaenus parvulus (Girard, 1853) (Cycloramphidae) consumed mainly Isopoda and Chilopoda (VAN SLuys et al. 2001). The diet of the population of Proceratophrys tupinamba Prado \& Pombal, 2008 (Cycloramphidae) at Ilha Grande was predominantly composed by Orthoptera (BoquIMPANIFreitas et al. 2002), whereas that of the congener $P$. boiei (WiedNeuwied, 1824) was mainly composed by Coleoptera at Guapimirim, state of Rio de Janeiro (T. Klaion, pers. comm.), and Orthoptera at Atibaia, state of São Paulo (GIARETTA et al. 1998), both located in the Atlantic Rainforest. The composition of the diet of frogs in the Atlantic forest litter varies with the species, probably as a result of differences in energy requirements and in the species body size as well as in food availability in the habitat.

The amount of plant remains we found in the stomachs of individuals of $I$. parva was low (5.6\%) and corresponded to fragments of dead leaves, suggesting that the occurrence of these items in the diet results from accidental ingestion during the capture of prey. The occurrence of plant material in the diet of many Brazilian frog species seems to result from accidental ingestion (e.g. VAN SLUYS et al. 2001, CANEDo et al. 2006, JoRdãoNogueira et al. 2006, Siqueira et al. 2006). In the Atlantic Rainforest, only the hylid Xenohyla truncata (Izecksohn, 1959) is known to effectively consume a large amount of small fruits (Silva \& Britto-Pereira 2006).

Tofт (1980a,b, 1981) analyzed the diet composition of leaf litter frogs of tropical forests of Peru and Panama and classified them in three general guilds according to their feeding habits: the "Ant specialists", the "Non-ant specialists" (which were those specialists in items different from ants) and "generalists". The wide diversity of types of items we recorded in the diet of $I$. parva of Serra da Concórdia (20 prey types) suggests a relatively generalized diet ("generalist" category of Toғт 1980a,b, 1981).

The absence of a significant relationship between the number of prey ingested and body size in Serra da Concórdia may result from the fact that this frog consumes relatively large prey, and most of the time, in small amounts (mean number of items by stomach $=2.8 \pm 2.5$ ), resulting in little variation in the number of ingested items.

The data indicated that I. parva tend to consume larger prey as body size increases. Possibly, as the frog increases in body size, the consumption of small prey become less energetically rewarding, whereas the consumption of larger prey 
favors a positive energy balance in terms of prey consumed. Additionally, this trend is expected for frogs, as they eat entire prey (e.g. Toft 1980a,b, Duellman \& Trueb 1986, Lima \& Moreira 1993, Lima 1998, Caldwell \& VitT 1999).

Our data showed that the leaf litter of the forest floor was the main microhabitat used by I. parva in Serra da Concórdia, indicating also a predominantly horizontal habitat use, similar to that observed for this species in other studies (HeYer et al. 1990, Haddad \& Sazima 1992, Izecksohn \& Carvalho-e-Silva 2001, Haddad \& Prado 2005, Pombal \& Haddad 2007). Other species in the genus Ischnocnema [e.g. I. guentheri (Steindachner, 1864) and I. octavioi (Bokermann, 1965)] and some other brachycephalids [e.g. Brachycephalus didactylus (Izecksohn, 1971) and B. ephippium (Spix, 1824)] also use the leaf litter of the forest floor as preferred microhabitat (e.g., Pombal et al. 1994, Rосна et al. 2000, 2001, 2007, Almeida-Gomes et al. 2008). At Serra da Concórdia, $I$. parva activity was primarily crepuscular (about $70 \%$ ), with most of the remaining individuals (around 26\%) being active at night. However, at Ilha Grande (Rocha et al. 2000), 70\% of individuals of $I$. parva found were active at night. This difference can be explained by the fact that, at Ilha Grande, there was actually no sampling on the crepuscular period, as the end of the afternoon sampling (17:30 h) corresponded to the start of the crepuscular period in our study. So, we consider I. parva to be active predominantly during crepuscular-nocturnal periods.

The data showed that, at Serra da Concórdia, I. parva has the highest known density for the species so far (ca. 25 ind./ $100 \mathrm{~m}^{2}$ ). The data available for other Atlantic forest areas showed significantly lower densities (around 2 to $10 \%$ of that found for the population from Serra da Concórdia). For example, at Ilha Grande the estimated density of I. parva was 2.1 ind./100 m² (Rосна et al. 2001), whereas in Cachoeiras de Macacu municipality, Rio de Janeiro, the estimated density for the population of $I$. parva was 0.5 ind. $/ 100 \mathrm{~m}^{2}$ (SiqueIra et al. 2009). These data suggests that, although this species tends to be one of the most abundant species in the communities where it occurs, its density is not constant among different areas, but rather tends to vary conspicuously, depending on the area. This variation in density may result from structural characteristics of the local environment such as depth and structure of the leaf litter layer and its components and the structure of the vegetation, inasmuch as these habitat elements affect the richness and abundance of frogs in the leaf litter (VAN SLuYs et al. 2007). Additionally, some of the differences may, in part, be due to the time of the year when the samplings were performed. Because data on density of I. parva are currently available for only a few areas, additional studies that focus on the density of species, in different areas and at different times of the year, are needed in order to better understand the role of seasonality and characteristics of the local environment on the density of I. parva along the Atlantic Forest.

Ovigerous females of I. parva from Serra da Concórdia produce on average about 25 oocytes per reproductive event. This figure was higher (mean of 11 oocytes) than that found for Ilha Grande (R.V. Marra pers. comm.). However, at Serra da Concórdia, the mean diameter of the eggs produced was about $1.1 \mathrm{~mm}$, whereas at Ilha Grande the eggs were considerably larger (about $1.7 \mathrm{~mm}$ diameter) (R.V. Marra, pers. comm.). These points to a trade-off between number and size of oocytes: at Ilha Grande, females produce smaller clutches with larger oocytes, whereas at Serra da Concórdia females produce larger clutches with comparatively smaller oocytes. Because females of the two populations are similar in size (mean SVL: $18.1 \pm 0.60 \mathrm{~mm}$ in Ilha Grande and $19.2 \pm 0.8 \mathrm{~mm}$ in Serra da Concórdia), these variations in sizes of clutches and oocytes among areas may result from differences in reproductive strategies of females in different areas of the Atlantic Rainforest. However, for a better understanding of the occurrence of this variation in reproductive strategy, it would be important to obtain information about these aspects from a greater number of areas and in different periods of the year. The number of eggs produced by females of I. parva, both from Serra da Concórdia and Ilha Grande, is within the range of what has been reported for other species of frogs with direct development, which may vary from one to about 100 oocytes (Duellman \& Trueb 1986, Donnelly 1999, Canedo \& Rickli 2006).

Our data showed that fertility increases with female size. We also found that the relationship between female size and mass of eggs produced was close to significance $(p=0.056)$. It seems that there is a biological trend for a positive correlation between these variables that also reinforces the trend observed between female body size and fertility. At Ilha Grande, there was not a significant relationship between body size of females and number of oocytes for I. parva (R.V. Marra, pers. comm.). The different results between our study and that of Ilha Grande may be a consequence of the small sample size in both studies. However, we cannot discard that differences between these populations might exist in this relationship. The increase in fertility as a function of the increase in female body size has also been found for other species of leaf litter frogs (see Duellman \& Trueb 1986, Donnely 1999, and reference therein). The mean reproductive effort of ovigerous females of $I$. parva from Serra da Concórdia was considerably higher (3\%) compared to that estimated for females from Ilha Grande (0.06\%) (R.V. Marra pers. comm.). This is another important variation among species' life history. The measurement of reproductive effort is an important component of many studies on reproductive strategies because it allows estimating parental investment in courtship and reproduction, in the proportional mass (= energy) invested in eggs and in the number of calories expended in gametogenesis and vitellogenesis (Duellman \& Trueb 1986).

The population of I. parva from Serra da Concórdia is sexually dimorphic in body size, with females growing larger than males, a similar result to that found for the population of Ilha Grande (R.V. Marra pers. comm.). Probably this trend results from intrasexual selection acting on females favoring larger females to produce larger clutches. 
The ecological differences between the insular and mainland populations at the Atlantic rainforest of the state of Rio de Janeiro may not be attributed to different selective pressures existing in those areas. It is necessary to consider that the differences in sampling periods between studies, in habitat structure and the small sample size of reproductive females for both areas can account for the observed interpopulational differences in the ecological aspects of I. parva.

\section{ACKNOWLEDGEMENTS}

This study was sponsored by Critical Ecosystem Partnership Fund, Conservação Internacional and Aliança para a Conservação da Mata Atlântica. We thank The Santuário Ecológico da Serra da Concórdia and the Grupo de Proteção Ambiental da Serra da Concórdia, through its Director, Roberto Lamego, for the permit and logistic support. CFDR (Proc. \# 307653/2003-0 and 476684/2008-0), MVS (Proc. \# 307773/2008-6 and 479874/ 2001-8), and MCK (Proc. \# 150353/2003-0) are grateful to the Conselho Nacional de Desenvolvimento Científico e Tecnológico (CNPq) and CFDR to Fundação de Amparo à Pesquisa do Estado do Rio de Janeiro (FAPERJ) through "Programa Cientistas do Nosso Estado" (Proc. \# E-26/102.404/2009). MCK acknowledges FAPERJ (Proc. \# E-26/171.168/2006). CFDR, MCK, VAM and MVS are associated to the Programa de Pós-Graduação em Ecologia e Evolução, Universidade do Estado do Rio de Janeiro, and CCS is associated to the Programa de Pós-Graduação em Ecologia, Universidade Federal do Rio de Janeiro. Graduate fellowships were granted by Coordenação de Aperfeiçoamento de Pessoal de Nível Superior to ACJSM and from CNPq to CCS and VAM. Currently VAM receives a Post-Doctoral grant from FAPERJ (E26/100.005/2009). We are also grateful to D. Vrcibradic who kindly revised de manuscript making helpful suggestions.

\section{LITERATURE CITED}

Almeida-Gomes, M.; M. Van Sluys \& C.F.D. Rocha. 2007. Ecological observations on the leaf-litter frog Adenomera marmorata in an Atlantic rain forest area of southeastern Brasil. Herpetological Journal 17 (2): 81-85.

Almeida-Gomes, M.; D. Vrcibradic; C.C. Siqueira; M.C. Kiefer; T. Klaion; P. Almeida-Santos; D. Nascimento; C.V. Ariani; V.N.T. Borges-Junior; R.F. Freitas-Filho; M. Van Sluys \& C.F.D. RoCHA. 2008. Herpetofauna of an Atlantic Rainforest area (Morro São João) in Rio de Janeiro State, Brazil. Anais da Academia Brasileira de Ciências 80 (2): 291-300.

Attias, N.; D.S.L. Raíces; F.S. Pessoa; H. Albuquerque; T. JordãoNogueira, T.C. Modesto \& H.G. Bergallo. 2009. Potential distribution and new records of Trinomys species (Rodentia: Echimyidae) in the State of Rio de Janeiro. Zoologia 26 (2): 305-315.

Bertoluci, J.; M. T. Rodrigues. 2002. Seasonal pattern of breadind activity of Atlantic Rainforest anurans at Boarcéia, Southeastern Brazil. Amphibia-Reptilia 23: 161-167.
Boquimpani-Freitas, L.; C.F.D. Rocha \& M. Van Sluys. 2002. Ecology of the horned leaf-frog, Proceratophrys appendiculata (Leptodactylidae), in an insular Atlantic Rain-forest area of Southeastern Brasil. Journal of Herpetology 36 (2): 318322.

Caldwell, J.P. \& L.J. VitT. 1999. Dietary asymmetry in leaf litter frogs and lizards in a transitional northem Amazonian rain forest. Oikos 84: 383-397.

CAnedo, C. \& E. Ricki. 2006. Female reproductive aspects and seasonality in the reproduction of Eleutherodactylus binotatus (Spix, 1824) (Amphibia, Leptodactylidae) in an Atlantic Rainforest fragment, Southeastern Brasil. Herpetological Review 37 (2): 149-151.

Canedo C.; J.P. Garcia; R. Fernandes \& J.P. Pombal JR. 2006. Diet of Pipa carvalhoi (Amphibia, Pipidae) is not influenced by female parental care. Herpetological Review 37 (1): 144-145.

CoRn, P.S. 1994. Straight-line drift fences and pitfall traps, p. 109-117. In: W.R. Heyer; M.A. Donnelly; R.W. McDiarmid; L.A.C. HAYEK \& M.S. Foster (Eds). Measuring and monitoring biological diversity: standard methods for amphibians. Washington, DC, Smithsonian Institution Press, 364p.

Crump, M.L. \& N.J. ScotT Jr. 1994. Visual encounter surveys, p. 84-92. In: W.R. Heyer; M.A. DonNelly; R.W. McDiarmid; L.A.C. HAYEK \& M.S. Foster (Eds). Measuring and monitoring biological diversity: standard methods for amphibians. Washington, DC, Smithsonian Institution Press, 364p.

Donnelly, A.M. 1999. Reproductive phenology of Eleutherodactylus bransfordii in Northeastern Costa Rica. Journal of Herpetology 33 (4): 624-631.

Duellman, W.E. \& L. Trueb. 1986. The Biology of Amphibians. New York, McGraw-Hill, 670p.

Dunham, A.E. 1983. Realized niche overlap, resource abundance, and intensity of interspecific competition, p. 261-280. In: R.B. Huey; E.R. PianKa \& T.W. Shoener (Eds). Lizard Ecology: studies of a model organism. Cambridge, Harvard University Press, 512p.

Frost, D.R. 2008. Amphibian species of the world: an online reference. Available online at: http://research.amnh.org/ herpetology/amphibia/index.php [Accessed: 12/VIII/2008]

Giaretta, A.A.; M.S. Araújo; H.F. Medeiros \& K.G. Facure. 1998. Food habits and ontogenetic diet shifts of the litter dwelling frog Proceratophrys boiei (Wied). Revista Brasileira de Zoologia 15 (2): 385-388.

Haddad, C.F.B. \& I. Sazima. 1992. Anfíbios anuros da Serra do Japi, p. 188-211. In: L.P. Morelatto (Ed.). História Natural da Serra do Japi: Ecologia e Preservação de uma Área Florestal do Sudeste do Brasil. Campinas, Editora da UNICAMP-FAPESP, 321p.

Haddad, C.F.B. \& C.P.A. Prado. 2005. Reproductive modes in frogs and their unexpected diversity in the Atlantic Forest of Brasil. BioScience 55 (3): 207-217.

Heinicke, M.P.; W.E. Duellman \& S.B. Hedges. 2007. Major Caribbean and Central American frog faunas originated by 
ancient oceanic dispersal. Proceedings of the National Academy of Sciences of the USA 104: 10092-97.

Heyer, W.R.; A.S. Rand; C.A.G. Cruz; O.L. Peixoto \& C.E. Nelson. 1990. Frogs of Boracéia. Arquivos de Zoologia, São Paulo 31 (4): 231-410.

Izecksohn, E. \& S.P. Carvalho-e-Silva. 2001. Anfíbios do Município do Rio de Janeiro. Rio de Janeiro, Editora Universidade Federal do Rio de Janeiro Brasil, 147p.

JAEGER, R.G. \& R.F. INGER. 1994. Quadrat sampling, p. 97-102. In: W.R. Heyer; M.A. Donnelly; R.W. McDiarmid; L.A.C. HayeK \& M.S. Foster (Eds). Measuring and monitoring biological diversity: standard methods for amphibians. Washington, DC, Smithsonian Institution Press, 364p.

Jordão-Nogueira, T.; D. Vrcibradic; J.A.L. Pontes; M. Van Sluys \& C.F.D. Rocha. 2006. Natural history traits of Crossodactylus aeneus (Anura, Leptodactylidae, Hilodinae) from an Atlantic Rainforest Area in Rio de Janeiro State, Southeastern Brasil. South American Journal of Herpetology 1 (1): 37-41.

LACERDA, P.; A.A.M. SARMENTO \& C.F.D. ROCHA. 1998. Variação sazonal na diversidade, abundância e produtividade de artrópodos em uma área de Mata Atlântica do Sudeste do Brasil (Casimiro de Abreu, RJ). Anais do VIII Seminário Regional de Ecologia 8: 847-856.

LIMA, A.P. 1998. The effects of size on the diets of six sympatric species of postmetamorphic litter anurans in Central Amazonia. Journal of Herpetology 32 (3): 392-399.

Lima, A.P. \& G. Moreira. 1993. Effects of prey size and foraging mode on the ontogenetic change in feeding niche of Colostethus stepheni (Anura: Dendrobatidae). Oecologia 95: 93-102.

LynCH, J.D. \& W.E. Duellman. 1997. Frogs of the genus Eleutherodactylus (Leptodactylidae) in western Ecuador: Systematics, ecology and biogeography. The University of Kansas Natural History Museum, Special Publication 23: 1-236.

MarRa, R.V.; M. Van StuYs \& C.F.D. Rocha. 2004. Food habits of Eleutherodactylus parvus (Anura: Leptodactylidae) at an Atlantic Rainforest Area, Southeastern Brasil. Herpetological Review 35 (2): 135-137.

Pombal JR, J.P. \& C.F.B. Haddad. 2007. Estratégias e modos reprodutivos em anuros, p. 101-116. In: L.B. NASCIMENTO \& M.E. Oliveira (Eds). Herpetologia no Brasil II. Belo Horizonte, Sociedade Brasileira de Herpetologia, 354p.

Pombal JR, J.P.; I. Sazima \& C.F.B. Haddad. 1994. Breeding behavior of the pumpkin toadlet, Brachycephalus ephippium (Brachycephalidae). Journal of Herpetology 28 (4): 516-519.

Powell, R.; J.S. Parmerlee Jr; M.A. Rice; \& D.D. Smith. 1990. Ecological observations on Hemidactylus brooki haititanus Meerwarth (Sauria: Gekkonidae) from Hispaniola. Caribbean Journal of Science 26: 67-70.

Rocha, C.F.D.; M. Van Sluys; M.A.S. Alves; H.G. Bergallo \& D.
VRCiBRADic. 2000. Activity of leaf-litter frogs: When should frogs be sampled. Journal of Herpetology 34 (2): 285-287.

Rocha, C.F.D.; M. Van Sluys; M.A.S. Alves; H.G. Bergallo \& D. VRCIBRADIC. 2001. Estimates forest floor litter frog communities: a comparison of two methods. Austral Ecology 26: 14-21.

Rocha, C.F.D.; D. Vrcibradic; M. C. Kiefer; M. Almeida-Gomes; V.N.T. Borges-Jr.; P.C.F. Carneiro; R.V. Marra; P. Almeida-Santos; C.C. Siqueira; P. Goyannes-Araújo; C.G.A. Fernandes; E.C.N. RUBião \& M. VAN SLUYs. 2007. A survey of the leaf-litter frog assembly from an Atlantic Forest area (Reserva Ecológica de Guapiaçu) in Rio de Janeiro State, Brasil, with na estimate of frog densities. Tropical Zoology 20: 99-108.

Santos, H.C.; C.F.D. Rocha \& H.G. Bergallo. 1998. A produtividade, diversidade e abundância da mesofauna do litter em dois segmentos de Mata Atlântica (Mata de Planície e Mata de Encosta) na Ilha do Cardoso, Cananéia, São Paulo. Anais do VIII Seminário Regional de Ecologia 8: 823-836.

Silva, H.R. \& M.C. Brito-Pereira. 2006. How much fruit do fruit-eating frogs eat? An investigation on the diet of Xenohyla truncata (Lissamphibia: Anura: Hylidae). Journal of Zoology 270: 692-698.

Siqueira, C.C.; C.V. Ariani; M. Van Sluys \& C.F.D. Rocha. 2006. Feeding ecology of Thoropa miliaris (Anura, Cycloramphidae) in four areas of Atlantic Rain Forest, Southeastern Brazil. Journal of Herpetology 40 (4): 520-525.

Siqueira, C.C.; D. Vrcibradic; M. Almeida-Gomes; V.N.T. Borges-JR; P. Almeida-Santos; M. Almeida-Santos; C.V. Ariani; D.M. Guedes; P. Goyannes-Araújo; T.A. Dorigo; M. Van Sluys \& C.F.D. Rocha. 2009. Density and richness of the leaf litter frogs of an Atlantic Rainforest area in Serra dos Órgãos, Rio de Janeiro State, Brazil. Zoologia 26 (1): 97-102.

ToFт, C.A. 1980a. Feeding ecology of thirteen syntopic species of anurans in a seasonal tropical environment. Oecologia 45: 131-141.

Toft, C.A. 1980b. Seasonal variation in populations of Panamanian litter frogs and their prey: A comparison of wetter and drier sites. Oecologia 47: 34-38.

ToFт, C.A. 1981. Feeding ecology of Panamania litter anurans: patterns in diet and foraging mode. Journal of Herpetology 15 (2): 139-144

Van SluYs, M.; C.F.D. Rocha \& M.B. Souza. 2001. Diet, reproduction, and density of the leptodactylid litter frog Zachaenus parvulus in an Atlantic Rain Forest of southeastern Brasil. Journal of Herpetology 35 (2): 322-325.

Van Sluys, M.; D. Vrcibradic; M.A.S. Alves; H.G. Bergallo \& C.F.D. Rосна. 2007. Ecological parameters of the leaf-litter frog community of an Atlantic Rainforest area at Ilha Grande, Rio de Janeiro State, Brazil. Austral Ecology 32: 254-260.

ZAR, J.H., 1999. Biostatistical Analysis. Englewood Cliffs, Prentice-Hall, 663p.

Submitted: 25.V.2009; Accepted: 28.I.2010.

Editorial responsibility: Fernando de Camargo Passos

ZOOLOGIA 27 (2): 201-208, April, 2010 